\title{
AN ANALYSIS ON CUSTOMER SATISFACTION, TRUST AND LOYALTY TOWARD ONLINE SHOP (A CASE STUDY OF TOKOPEDIA.COM)
}

\author{
Ayudya Dhiranty ${ }^{* 1}$, Budi Suharjo ${ }^{* *}$, and Gendut Suprayitno ${ }^{* *}$ \\ *) School of Business, Bogor Agricultural University \\ SB IPB Building, Pajajaran Road, Bogor, Indonesia 16151 \\ **) Department of Mathematics, Faculty of Mathematics and Natural Sciences, Bogor Agricultural University \\ Meranti Road, IPB Darmaga Campus, Bogor 16680 \\ ${ }^{* * *}$ Program Master of Industrial Engineering, National Institute of Science and Technology \\ Campus III ISTN, PLN Durentiga Road, Pasar Minggu, Jakarta 12760
}

\begin{abstract}
In reference to the results of national research conducted by the Association of Internet Service Providers Indonesia (APJII) in cooperation with PusKaKom UI, the number of internet users (88.1 million) and its penetration (34.9\%) in Indonesia has gradually increased. Also, the research identifies the issues of satisfaction, trust and loyalty in online shopping. The presence of actors in e-commerce business benefits the customers to personally choose the site to shop. The strategies to keep customer satisfaction trust and loyalty on one site challenge the actors in the business. In this regard, this paper examines customer satisfaction, trust and loyalty in online shopping in reference to the Quality User Interface (UIQ), Information Quality (IQ), Perceived Security Risk (PSR) and Perceived Privacy (PP) variables with case studies On Tokopedia.com. The study was conducted with 211 respondents by using self-administrated questionnaires in Survey Monkey platform in Jakarta and Bogor. The data were analyzed by using Structural Equation Modeling (SEM). Thus, the results show that the variables of UIQ, $I Q, P S R$ and PP have an influence on satisfaction and trust. The variable of satisfaction has an influence on trust. However, these variables have no direct influence on loyalty.
\end{abstract}

Keywords: e-commerce, satisfaction, trust, loyalty, SEM

\begin{abstract}
ABSTRAK
Hasil riset nasional yang dilakukan oleh Asosiasi Penyelenggara Jasa Internet Indonesia (APJII) bekerjasama dengan PusKaKom UI, pengguna internet Indonesia (88.1 juta) dan penetrasinya (34.9\%) mengalami peningkatan. Namun, dari riset juga ditemukan bahwa adanya isu-isu kepuasan, kepercayaan dan loyalitas dalam berebelanja online. Adanya banyak pelaku dalam bisnis ecommerce membuat konsumen memiliki keuntungan untuk memilih situs yang menjadi tempat berbelanja. Bagaimana membuat konsumen terpuaskan dan percaya sampai dengan setia pada satu situs menjadi tantangan para pelaku bisnis. Sehubungan dengan hal tersebut, tulisan ini akan meneliti kepuasan, kepercayaan dan loyalitas konsumen dalam berbelanja online yang ditnjau dari variabel User Interface Qualiy (UIQ), Information Quality (IQ), Perceived Security Risk (PSR) dan Perceived Privacy (PP) dengan studi kasus pada Tokopedia.com. Penelitian dilakukan dengan 211 responden menggunakan self-administrated questionnaire dengan platform SurveyMonkey di Jakarta dan Bogor. Analisis data menggunakan Sturctural Equation Modeling (SEM). Hasil menunjukan bahwa variabel UIQ, IQ, PSR dan PP mempunyai pengaruh terhadap kepuasan dan kepercayaan. Variabel kepuasan mempunyai pengaruh terhadap kepercayaan. Namun variable tersebut tidak berpengaruh langsung kepada loyalitas.
\end{abstract}

Kata kunci: ecommerce, kepuasan, kepercayaan, loyalitas, SEM

\footnotetext{
${ }^{1}$ Corresponding author:

Email: ayudyadhiranty@gmail.com
} 


\section{INTRODUCTION}

E-commerce business is currently growing rapidly in accordance with the development of internet users in Indonesia. In reference to the results of national research conducted by the Association of Internet Service Providers Indonesia (APJII) in cooperation with PusKaKom UI, the number internet users in Indonesia and its penetration has increased. General Chairman of APJII, Semuel A. Pangerapan states that the year of 2014 shows that the number of users had increased by 88.1 million or, in other words, the penetration level reached up to $34.9 \%$. The number of users is adjusted to the number of population in Indonesia in line with the data of Central Bureau of Statistics (BPS) in 2014; i.e. 252 million inhabitants. Thus, in terms of population, internet users experienced a growth of 16.2 million users in which it increases from 71.9 million to 88.1 million users. Nonetheless, online trading activity is still in the seventh rank in people's activity when accessing the internet. $72.7 \%$ of Indonesian internet users have never performed online shopping.

One of the largest e-commerce websites in Indonesia is Tokopedia. Tokopedia allows every individual, small shops/businesses and brands to open and manage online stores. Currently, Tokopedia has placed the 8 th position as the most visited website in Indonesia and the top position in the e-commerce category. Tokopedia.com was officially launched to public on August 17, 2009 under the auspices of PT. Tokopedia owned by William Tanuwijaya and Leontinus Alpha Edison on February 6,2009 . Since it was officially launched, PT. Tokopedia has managed to be one of the internet companies in Indonesia with a highly rapid growth.

Concerns regarding confidence in safety, privacy and service fulfillment while conducting online business have been identified as a significant barrier to the rapid adoption of online trading and economic growth (Brendon, 2002). Customer loyalty in online shopping plays an important role in the e-commerce business. In general, customer loyalty is closely related to the profit and long-term growth of a company. Reicheld and Schefter (2000) argue that the cost incurred to acquire online customers can lead to less benefit. Hoffman and Novak (2000), in their study, found that online businesses, especially e-commerce, have difficulty in maintaining customer loyalty despite the growth of $\mathrm{B} 2 \mathrm{C}$ e-commerce.
One of the researches utilized as the benchmark of this study is the one conducted by Zins (2001) suggesting that high customer satisfaction has a major impact on loyalty. Nonetheless, the impact is quite complex. Fisher (2001) believes that customer satisfaction only affects customer preferences in choosing service providers and products. Cyr (2008) found that customer satisfaction towards the website is closely related to loyalty in three countries: Canada, Germany and China.

The information quality of a product and service presented on the website is also one of the factors influencing customer satisfaction and trust. Moreover, Park and Kim (2003) prove that it indeed has a direct influence. Although Cyr (2008) in his study argues the opposite statement about Canada, he reveals the same notion in German and China.

Kolsaker and Payne (2002) suggest that safety in online transaction reflects a robust process of data transmission, storage and payment method. Negligence in maintaining those matters will be an obstacle in e-commerce development (Dong-Her et al. 2004). Flavia'n and Guinaly'u (2006) demonstrate that trust on the internet is partially influenced by the security of customer data storage.

The presence of numbers of actors in e-commerce business enables customers to have the advantage to choose which site to shop. How to maintain customers' satisfaction, trust, and loyalty on one site becomes the primary challenge. In relation to this matter, the purpose of this research is to analyze customer shopping satisfaction and trust, examine the influence of customer satisfaction on customer trust, and analyze the influence of customer satisfaction and trust on customer loyalty in Tokopedia.

This study is limited by a number of matters; i.e. testing was only conducted to the customers of Tokopedia in Jakarta and Bogor who had performed purchases in Tokopedia at least twice in the previous year.

\section{METHODS}

This research was conducted in Jakarta and Bogor. Site selection was conducted due to the accessibility and suitability of the research objects; i.e. two urban cities in Indonesia. The research activities covered the 
following: proposal, data collection, data processing, data analysis and preparation of research thesis report in October 2016.

The types of data required in this study are primary and secondary data, both in forms of quantitative and qualitative. Primary data were obtained from the respondents' responses in the questionnaires compiled in one. Meanwhile, the secondary data obtained from literature studies on a number of scientific publications; e.g. research reports, research journals, theses and dissertations. In addition, articles that can be accessed online and in the library are also utilized as complementary materials, so that the secondary data can be used as a reference in interpreting the results of primary data.

The samples were taken by non-probability sampling in which each member of the population did not have the same opportunity. Purposive sampling was utilized by selecting the samples on the basis of particular considerations. The criteria of the selected respondents were those who made purchases in Tokopedia at least twice in the previous year.

This research used descriptive method and case study. The descriptive method aims to provide an overview of an on-going matter at the time of research and to precisely describe the facts and relationship occurred between the examined phenomena (Nazir, 1988). This was performed to answer questions concerning a situation at the time of research process; i.e. to analyze the qualities of website, information, safety and confidentiality of B2C e-commerce along with the main factors influencing the satisfaction and trust.

The case study method required a detailed, thorough and comprehensive research of a particular object, that is usually relatively small over a period of time. The advantage of this method is that the results can support larger studies later on. This study was conducted by distributing self-administered questionnaires with the surveymonkey platform. The number of questionnaires is at least five times more than the coefficient of examined variables. Subsequently, as many as 211 questionnaires are distributed to respondents (Wijanto, 2008). Questionnaire link was shared via messenger groups (WhatsApp and LINE) and various social media platforms (Facebook, Instagram, Twitter and Path). The Likert scale was used in the questionnaire to measure the level of respondents' approval or disapproval towards a series of questions measuring an object (Istijanto, 2005).

This scale is commonly used in questionnaires and is the most widely used scale in research and survey. The research model used in this study was tiered structure model. Meanwhile, to test the proposed hypothesis, SEM (Structural Equation Modeling) technique was utilized and operated through Linear Structural Relationship (LISREL) program. SEM was utilized in this study due to its function as a set of statistical techniques which allows the testing of a relatively "complicated" series of relationships simultaneously. Modeling through SEM also enables to answer both regressive and dimensional research questions (i.e. measuring the dimensions of a concept) (Ferdinand, 2002). The framework of the research is explained more thoroughly in Figure 1.

\section{Hypotheses}

In reference to the research framework, eleven hypotheses were formulated in this study. The variable specifications, as proposed by Eid (2011), can be seen in Table 1.

H1a: An increase in user interface quality (UIQ) has a positive influence on customer satisfaction (ECS)

H1b: An increase in user interface quality (UIQ) has a positive influence on customer trust (ET)

H2a: An increase in information quality of goods and services (IQ) has a positive influence on ECS

H2b: An increase in information quality of goods and services (IQ) has a positive influence on ET

H3a: If perceived security risk (PSR) decreases, ECS increases

$\mathrm{H} 3 \mathrm{~b}$ : If perceived security risk (PSR) decreases, ET increases

$\mathrm{H} 4 \mathrm{a}$ : If privacy risk (PP) decreases, ECS increases

$\mathrm{H} 4 \mathrm{~b}$ : If privacy risk (PP) decreases, ET increases

H5 : An increase in ECS has an influence on customer loyalty

H6 : An increase in ECS positively influences the customer loyalty (ECL)

H7 : An increase in ET positively influences the customer loyalty (ECL) 


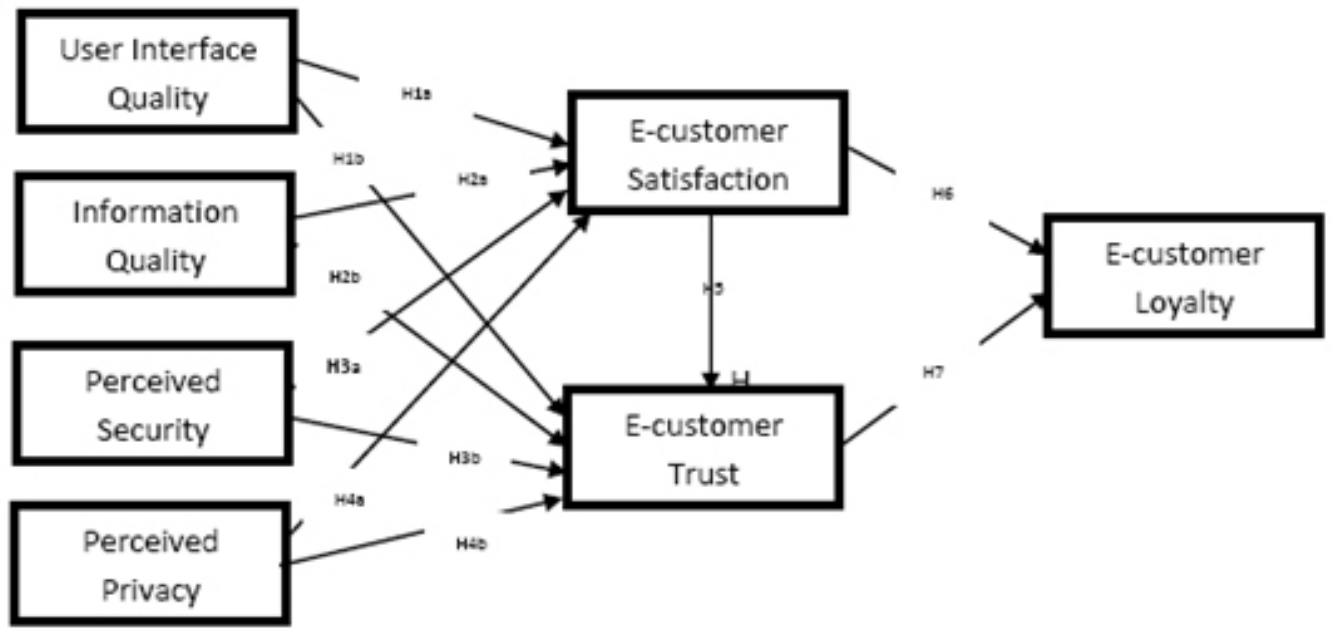

Figure 1. Research framework

Table 1. Variable Specifications

\begin{tabular}{|c|c|}
\hline Variable & Definition \\
\hline $\begin{array}{l}\text { User interface } \\
\text { Quality }\end{array}$ & $\begin{array}{l}\text { Customer perceptions towards the } \\
\text { e-commerce interface quality on the } \\
\text { website }\end{array}$ \\
\hline $\begin{array}{l}\text { Informat } \\
\text { Quality }\end{array}$ & $\begin{array}{l}\text { Customer perceptions towards the } \\
\text { information quality of products and } \\
\text { services provided by the website }\end{array}$ \\
\hline Risk & $\begin{array}{l}\text { Customer perceptions towards the safety } \\
\text { in online transaction }\end{array}$ \\
\hline $\begin{array}{l}\text { Perceived } \\
\text { Privacy }\end{array}$ & $\begin{array}{l}\text { Customer perceptions towards the } \\
\text { capability to control others and/or } \\
\text { maintain confidentiality in the online } \\
\text { environment }\end{array}$ \\
\hline $\begin{array}{l}\text { Customer } \\
\text { Trust }\end{array}$ & $\begin{array}{l}\text { Desire or trust of customer to depend on } \\
\text { the partner }\end{array}$ \\
\hline $\begin{array}{l}\text { Customer } \\
\text { Satisfaction }\end{array}$ & $\begin{array}{l}\text { Satisfaction towards the provided } \\
\text { services }\end{array}$ \\
\hline $\begin{array}{l}\text { Customer } \\
\text { Loyalty }\end{array}$ & $\begin{array}{l}\text { Desire of customers to visit the website } \\
\text { more often and maintain the purchases }\end{array}$ \\
\hline
\end{tabular}

\section{RESULTS}

\section{SEM Analysis}

The latent variables examined in this study consist of User Interface Quality, Information Quality, Perceived Safety Risk, Perceived Privacy, Customer Trust, Customer Satisfaction and Customer Loyalty. The data were analyzed by using SEM with Lisrel software 8.7 Version to examine the dimension measurement model with respective representative indicators.

Furthermore, the validity test was conducted, and this could be identified in reference to the value of Standardized Loading Factor (SLF). SLF reflects observed variable capabilities in measuring latent variables. Good SLF value is $\geq 0.50$, while good Construct Reliability (CR) value is $\geq 0.70$, and good Variance Extracted (VE) is $\geq 0.50$.

\section{User Interface Quality Variable}

Job satisfaction variable is the first order variable consisting of four indicators. The results of the measurement model test of each first order latent variable of its support are as follow. The result of measurement model analysis for User interface Quality latent variable on the observed variable can be seen in Figure 2. Based on the path diagram, validity and reliability tests were performed by using Standardized Loading Factor (SLF) values, as well as the value of variance error. The SLF result shows that all observed variables of Quality User interface in path diagrams are valid because it has a value of SLF $\geq 0.50$ and good reliability with $C R$ values $\geq 0.70$ and $\mathrm{VE} \geq 0.50$. The result of validity and reliability tests for Quality User interface variable can be seen in Table 2 .

\section{Information Quality Variable}

The Information Quality variable is the first order variable consisting of four indicators. The results of the measurement model test of each first order latent variable and its support are presented as follow. The result of measurement model analysis for Information Quality latent variable on the observed variable can be seen in Figure 3. Moreover, validity and reliability tests were performed by using Standardized Loading Factor (SLF) values, as well as the value of variance error. The result shows that all observed variables of Information Quality in path diagrams are valid because 
it has a value of SLF $\geq 0.50$ and good reliability with CR values $\geq 0.70$ and $\mathrm{VE} \geq 0.50$ (Tabel 3 ).

\section{Perceived Security Risk Variable}

Perceived Security Risk variable is the first order variable consisting of four indicators. The results of the measurement model test of each first order latent variable and its supports are presented as follow. The result of measurement model analysis for Perceived Security Risk latent variable on the observed variable can be seen in Figure 4. Based on the path diagram (Figure 4), the validity and reliability tests were performed by using Standardized Loading Factor (SLF) values, as well as the value of variance error. The result shows that all observed variables of Quality User interface in path diagrams are valid because it has a value of SLF $\geq 0.50$ and good reliability with CR values $\geq 0.70$ and $\mathrm{VE} \geq 0.50$ (Table 4 ).

\section{Perceived Privacy Variable}

The Perceived Privacy variable is the first order variable consisting of five indicators. The results of the measurement model test of each latent variable first order are supported as follow. The result of measurement model analysis for Perceived Privacy latent variable on the observed variable can be seen in Figure 5.

Table 2. Validity and reliability of user interface quality latent variable

\begin{tabular}{ccccc}
\hline Indicator & Loading Factor & ei & CR & VE \\
\hline UIQ1 & 0.95 & 0.10 & & \\
UIQ2 & 0.89 & 0.20 & & \\
UIQ3 & 0.99 & 0.02 & 0.92 & 0.76 \\
UIQ4 & 0.61 & 0.63 & & \\
\hline
\end{tabular}

Table 3. Validity and reliability of information quality latent variable

\begin{tabular}{ccccc}
\hline Indicator & Loading Factor & ei & CR & VE \\
\hline IQ1 & 0.98 & 0.04 & & \\
IQ2 & 0.88 & 0.22 & & \\
IQ3 & 0.86 & 0.26 & & 0.79 \\
IQ4 & 0.84 & 0.29 & & \\
\hline
\end{tabular}

Table 4. Validity and reliability of perceived security risk latent variables

\begin{tabular}{|c|c|c|c|c|}
\hline Indicator & Loading Factor & ei & CR & $\mathrm{VE}$ \\
\hline PSR1 & 0.92 & 0.15 & \multirow{4}{*}{0.95} & \multirow{4}{*}{0.84} \\
\hline PSR2 & 0.95 & 0.10 & & \\
\hline PSR3 & 0.89 & 0.20 & & \\
\hline \multirow[t]{2}{*}{ PSR4 } & 0.91 & 0.18 & & \\
\hline & UIQ1 & & & \\
\hline & UIQ2 & & & \\
\hline & UIQ3 & & & \\
\hline & UIQ4 & & & \\
\hline
\end{tabular}

Figure 2. Path diagram of user interface quality latent variable

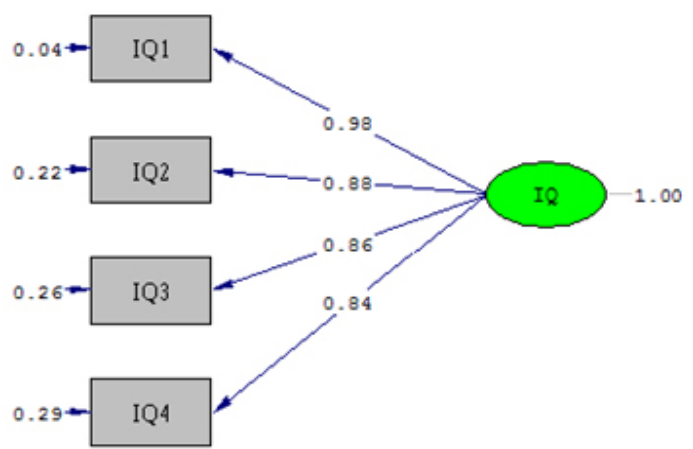

Chi-Square $=0.86, \mathrm{df}=2, \mathrm{p}-\mathrm{value}=0.64943, \mathrm{RMSEA}=0.000$

Figure 3. Path diagram of information quality latent variable

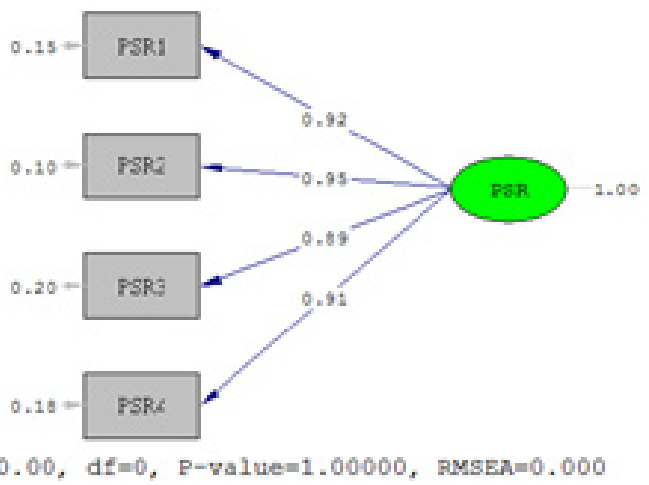

Figure 4. Path diagram of perceived security risk latent variable 
In reference to the path diagram above, the validity and reliability tests were performed by using Standardized Loading Factor (SLF) values, as well as the error variance value. The result of validity and reliability tests for Perceived Privacy variable can be seen in Table 5. It shows that all of the observed variables of Perceived Privacy on the path diagram are valid because its SLF value is $\geq 0.50$ and a good reliability with $C R$ value of $\geq 0.70$ and VE 0.50 .

\section{Customer Trust Variable}

The Customer Trust variable is the first order variable consisting of five indicators. The results of the measurement model test of each first order latent variable and its supports are presented as follow. The result of measurement model analysis for Customer Trust latent variable on the observed variable can be seen in Figure 6.

Based on the path diagram in Figure 6, the validity and reliability tests were performed by using Standardized Loading Factor (SLF) values, as well as the variance error value. The validity and reliability test results for Customer Trust variables can be seen in Table 6. All of the observed variables of Customer Trust on path

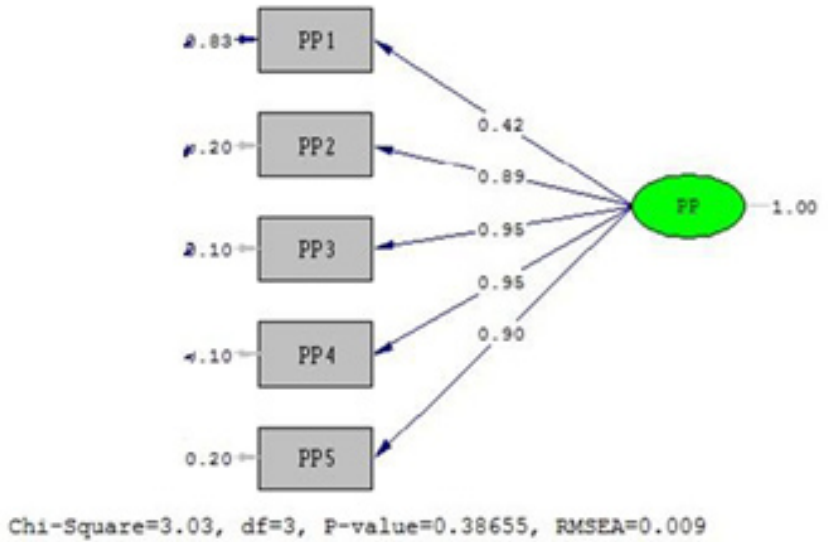

Figure 5. Path diagram of perceived privacy latent variable

Table 5. Validity and reliability of perceived privacy latent variable

\begin{tabular}{ccccc}
\hline Indicator & Loading Factor & ei & CR & VE \\
\hline PP1 & 0.42 & 0.83 & & \\
PP2 & 0.89 & 0.20 & & \\
PP3 & 0.95 & 0.10 & 0.92 & 0.71 \\
PP4 & 0.95 & 0.10 & & \\
PP5 & 0.90 & 0.20 & & \\
\hline
\end{tabular}

diagram are valid because of the SLF value $\geq 0.50$ and good reliability with $C R$ value $\geq 0.70$ and $\mathrm{VE} \geq 0.50$.

\section{E-customer Satisfaction Variable}

E-customer Satisfaction Variable is the first order variable consisting of four indicators. The results of the measurement model test of each first order latent variable and its supports are presented as follow. The result of measurement model analysis for the latent variable of Customer Satisfaction on the observed variable can be seen in Figure 7. The result of validity and reliability test for Customer Satisfaction variable can be seen in Table 7 .

\section{E-customer Loyalty Variable}

E-customer Loyalty Variable is the first order consisting of four indicators. The results of the measurement model test from each first order latent variable and its supports are presented as follow. The results of measurement model analysis for the latent variable of E-customer Loyalty on the observed variables can be seen in Figure 8 . The result of validity and reliability test for Customer Loyalty variable can be seen in Table 8.

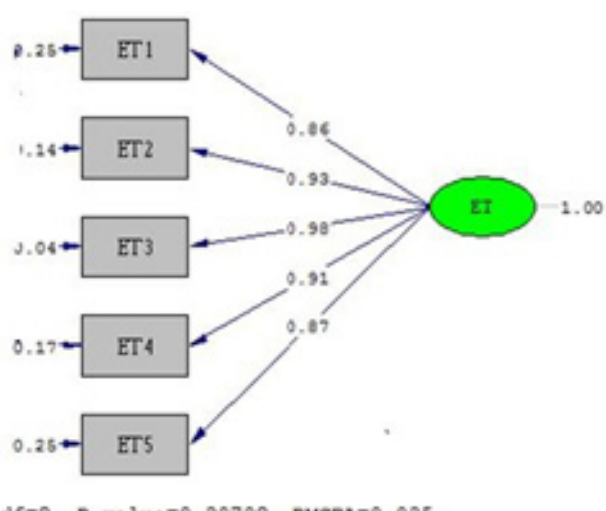

Ch1-Square $=2.36, d f=2, p-v a l u e=0.30702$, RysEA $=0.035$

Figure 7. Path diagram of the e-commerce trust latent variable

Table 7. validity and reliability of the e-customer trust latent variable

\begin{tabular}{ccccc}
\hline Indicator & Loading Factor & ei & CR & VE \\
\hline ET1 & 0.86 & 0.25 & & \\
ET2 & 0.93 & 0.14 & & \\
ET3 & 0.98 & 0.04 & 0.96 & 0.83 \\
ET4 & 0.91 & 0.17 & & \\
ET5 & 0.87 & 0.25 & & \\
\hline
\end{tabular}




\section{SEM Equity Result}

Based on T-Count results, there are several variables consisting of four exogenous variables; i.e. user interface quality (UIQ), information quality (IQ), perceived security risk (PSR) and perceived privacy (PP), three endogenous variables, e-customer satisfaction ECS), e-customer trust (ET) and e-customer loyalty (ECL) and forty-one variable coefficients. The value in one coefficient explains that a variable influences other variables significantly.

If the number exceeds $t$ table (1.96), then the value is significant and the hypothesis is accepted. The result of $\mathrm{T}$ count highlights one insignificant coefficient value i.e. the influence of ECS on ECL. This explains that customer satisfaction has no effect on loyalty towards Tokopedia. The values in the coefficients in Figure 9 show the level of influence of one variable to another. If the value is smaller or equal to $p$-value, then the hypothesis is rejected.

\section{Hypothesis Testing}

Hypothesis testing is based on the values in the structural model analysis, and the significance level of the path coefficient is obtained from the values of $t$-value and

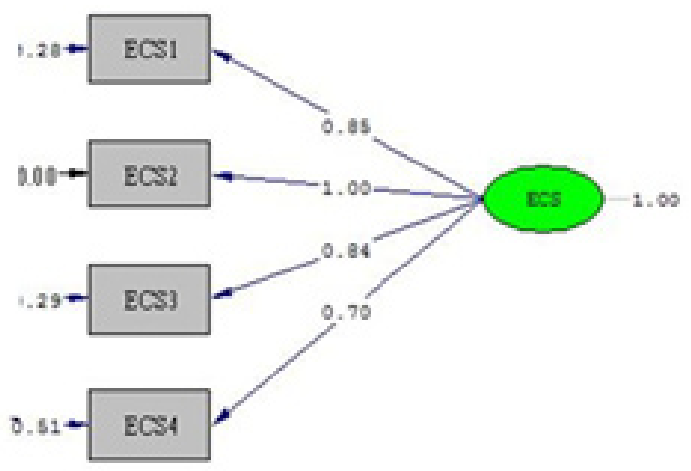

Ch1-Square $=0.00, d f=0, p-v a l u e=1.00000$, Rucsea $=0.000$

Figure 7. Path diagram of customer satisfaction latent variable

Table 7. Validity and reliability of customer satisfaction latent variables

\begin{tabular}{ccccc}
\hline Indicator & Loading Factor & ei & CR & VE \\
\hline ECS1 & 0.85 & 0.28 & & \\
ECS2 & 1.00 & 0.00 & & \\
ECS3 & 0.84 & 0.29 & 0.91 & 0.73 \\
ECS4 & 0.70 & 0.51 & & \\
\hline
\end{tabular}

the standardized path coefficient. Moreover, the limit value or threshold of hypothesis testing; i.e. the t-value of loading factor is greater than the critical value $(\geq 1.96)$ and the value of standardized path coefficient (p) $\geq 0.05$. Hence, the summary of hypothesis testing results can be seen in the following table of structural test result model. If $\mid \mathrm{t}$ count $\mid>t$ table (1.96), then it is significant.

In reference to Table 9, UIQ variable has a significant value. That is, UIQ has a positive influence on customer satisfaction and trust. In addition, the research shows similar results to the study conducted by Cyr (2008). Similarly, the IQ variable has a significant value in which it has a positive influence on satisfaction and trust; furthermore, the result is in accordance with the study performed by Park and Kim (2003).

PSR variable has a significant influence on satisfaction and trust. That is, the less risk in doing online shopping, the more satisfied customers will be and trust Tokopedia. This result proves the research conducted by Flavia'n and Guinaly'u (2006). Morevoer, this also applies to PP variables in which the less risk of data confidentiality will increase the levels of satisfaction and trust towards Tokopedia.

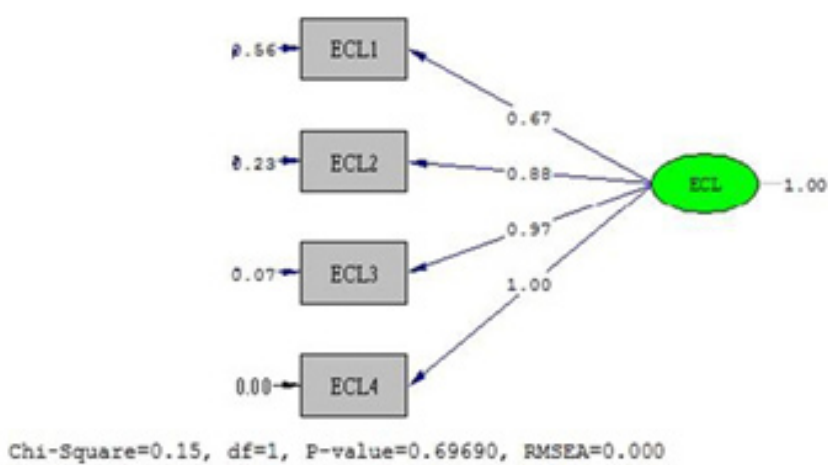

Figure 8. Path diagram of e-customer loyalty latent variable

Table 8. Validity and reliability of e-customer loyalty latent variables

\begin{tabular}{ccccc}
\hline Indicator & Loading Factor & ei & CR & VE \\
\hline ECL1 & 0.85 & 0.28 & & \\
ECL2 & 1.00 & 0.00 & & \\
ECL3 & 0.84 & 0.29 & & 0.73 \\
ECL4 & 0.70 & 0.51 & & \\
\hline
\end{tabular}




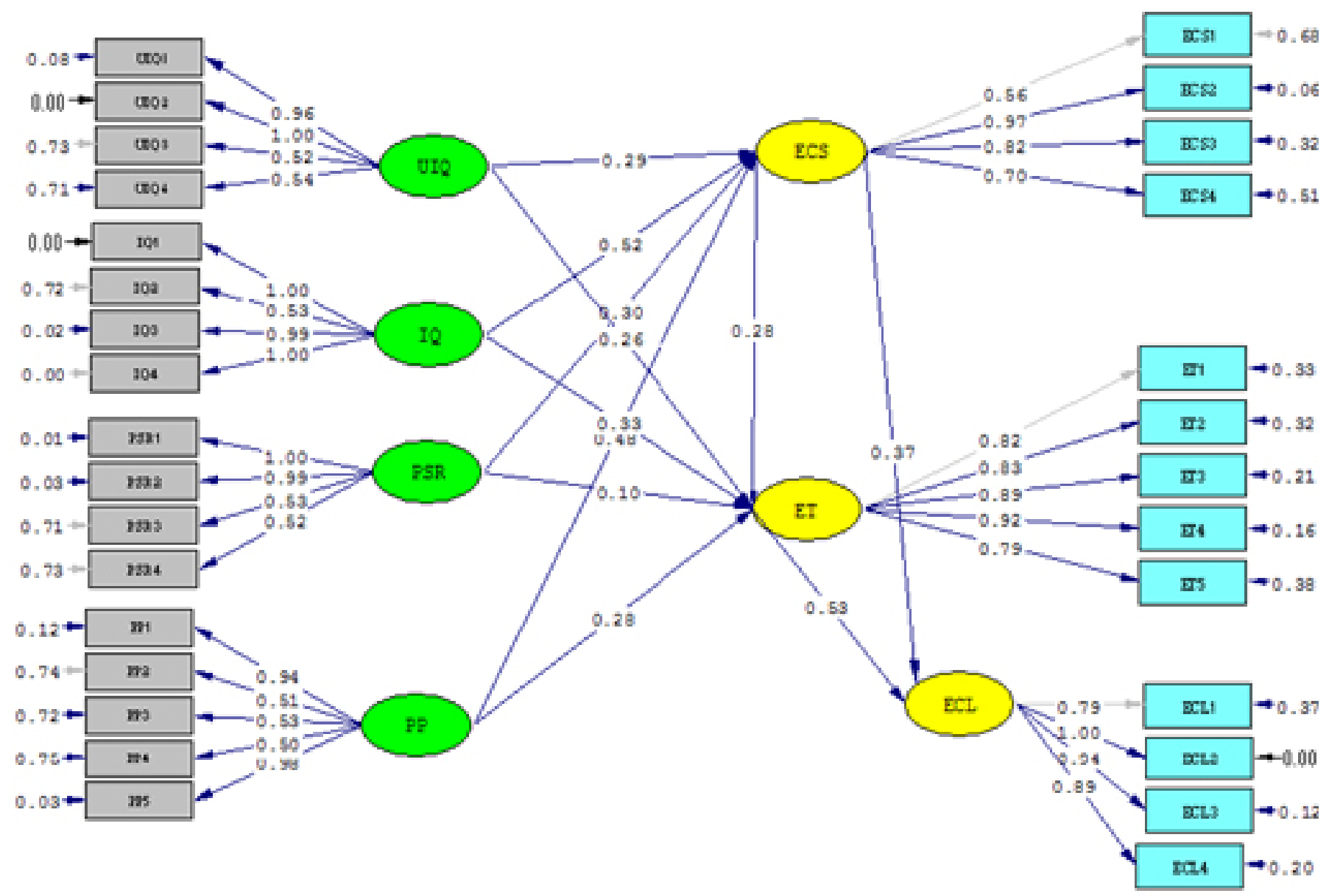

Chi-Square $=657.21$, df $=318, \mathrm{P}-\mathrm{value}=0.00000$, FuSER $=0.071$

Figure 9. The level of influence of one variable to another

Table 9. Hypothesis testing

\begin{tabular}{clccc}
\hline Hypothesis & \multicolumn{1}{c}{ Description } & Standardized loading factor & $\mid$ T Count $\mid$ & Information \\
\hline H1a & UIQ $\rightarrow$ ECS & 0.29 & 5.97 & Significant \\
H1b & UIQ $\rightarrow$ ET & 0.26 & 4.72 & Significant \\
H2a & IQ $\rightarrow$ ECS & 0.52 & 26.09 & Significant \\
H2b & IQ $\rightarrow$ ET & 0.33 & 10.16 & Significant \\
H3a & PSR $\rightarrow$ ECS & 0.30 & 7.38 & Significant \\
H3b & PSR $\rightarrow$ ET & 0.10 & 2.05 & Significant \\
H4a & $\mathrm{PP} \rightarrow$ ECS & 0.48 & 24.45 & Significant \\
H4b & $\mathrm{PP} \rightarrow$ ET & 0.28 & 10.01 & Significant \\
H5 & ECS $\rightarrow$ ET & 0.28 & 5.04 & Significant \\
H6 & ECS $\rightarrow$ ECL & 0.37 & 1.65 & Not significant \\
H7 & ET $\rightarrow$ ECL & 0.53 & 3.71 & Significant \\
\hline
\end{tabular}

The satisfaction variable (ECS) evidently has an influence on trust (ET); i.e. the more satisfied the customers, the higher the trust level. Nevertheless, if seen from the insignificant value, satisfaction does not necessarily drive the customers to be loyal. This finding is in line with the notion proposed by Zins
(2001) and Fisher (2001), arguing that the relationship of satisfaction and loyalty is complex. Lastly, the trust variable has a significant value to loyalty. That is, the higher the trust level towards Tokopedia, the higher tendency of costumers to be loyal. 


\section{Managerial Implications}

In reference to the results of the study, some advice can be given to Tokopedia in order to maintain its excellence and improve its service quality. Tokopedia is proven to be a trustworthy e-commerce business platform. Nonetheless, there are still customers who feel insecure to provide private information such as credit cards to shop online. Consequently, communication intended to ensure that all payment portals offered by Tokopedia need to be improved and secured.

The performance of Tokopedia is proven to satisfy customer expectations. To maintain its reputation, Tokopedia can do sustainable creative marketing to keep its recognition from customers. Thus, to increase customer loyalty, Tokopedia can conduct various promotional activities; in terms of visual aspect, Tokopedia can put all information listed in a more interesting way and increase the effectiveness of search feature performed by customers during the shopping activity in Tokopedia. Meanwhile, to reduce the risks of customers in providing data, both personal and financial, Tokopedia can socialize its applied system; e.g. when there is a new system, and others.

\section{CONCLUSIONS AND RECOMMENDATIONS}

\section{Conclusions}

This study aims to analyze the customer satisfaction, trust and loyalty towards Tokopedia examined based on user interface quality, information quality, perceived security risk and perceived privacy. In reference to the results and discussion, it is concluded that (1) the quality of the website, information, security and confidentiality are the factors influencing the satisfaction and trust of Tokopedia customers; (2) the satisfaction of shopping activity has an influence on trust but not necessarily on loyalty; (3) customers who already have trust towards Tokopedia, tend to be loyal.

\section{Recommendations}

To complement the limitations of this study, further research is recommended; i.e. by examining more diverse and detailed satisfaction, trust and loyalty variable indicators. For instance, the types of products most frequently purchased in Tokopedia, customer service, and etc. Further research can also be conducted by adding other potential variables influencing the E-customer satisfaction, trust and loyalty; such as price. Moreover, conducting research on more advanced platforms of online shopping application similar to Tokopedia with the aim to see customer behavior in online shopping in Indonesia in general is also encouraged.

\section{REFERENCES}

Alexa. 2016. Top sites in Indonesia. http://www.alexa. com/topsites/countries/ID [ 1 Oktober 2016]

Asosiasi Penyelenggara Jasa Internet Indonesia. 2014. Profil pengguna internet Indonesia 2014. https://apjii.or.id/download/file/profil-pengguna internetindonesia2014.pdf [1Juni 2015].

Brendon CF. 2002. In ecommerce, customer trust is no longer an option: it is the requirement for success. Annual Quality Congress Proceedings; 2002 May; Denver, Colorado. Denver: American Society for Quality

Cyr D. 2008. Modeling Website design across cultrues: relationship to trust, satisfaction and e-loyalty. Journal of Management Information Systmes 24(4):47-72. https://doi.org/10.2753/MIS07421222240402 .

Dong-Her S, Hsiu-Sen S, Chun-Yuan C, Lin B. 2004. Internet security: malicious e-mails detection and protection. Industrial Management \& Data Systems 104(7):13-23. https://doi. org/10.1108/02635570410550278.

Eid MI. 2011. Determinants of e-commerce customer satisfaction, trust and loyalty in Saudi Arabia. Journal of Electronic Commerce Research 12(1):78-93.

Ferdinand A. 2002. Structural Equation Modelling Dalam Peneltian Manajemen. Edisi 2, Seri Pustaka Kunci 03/BP . Semarang: UNDIP.

Fisher A. 2001. Winning the battle for customers. Journal of Financial Sevices Marketing 6(2):77-93. https://doi.org/10.1057/palgrave. fsm.4770042.

Flavia'n C, Guinaly'u M. 2004. Customer trust, perceived security and privacy policy: three basic elements of loyalty to a website. Industrial Management \& Data Systems 104(9):744-755.

Hoffman D, Novak T. 2000. How to acquire customers on the web. Harvard Business Review 78(3):179185.

Istijanto. 2005. Riset Sumber Daya Manusia. Jakarta: 
P-ISSN: 2407-5434 E-ISSN: 2407-7321

Accredited by Ministry of RTHE Number 32a/E/KPT/2017

PT. Gramedia Pustaka Umum.

Kolsaker A, Payne C. 2002. Engendering trust in e-commerce: a study of genderbased concerns.Marketing Intellingence \& Planning 20(4):206-214. https://doi. org/10.1108/02634500210431595.

Park C, Kim Y. 2003. Identifying key factors affecting consumer purchase behavior in an online shopping context. International Journal of Retail \& Distribution Management 31(1):16-29. https://doi.org/10.1108/09590550310457818.

Nazir M. 1988. Metode Penelitian. Jakarta: Ghalia Indonesia.
Available online at http://journal.ipb.ac.id/index.php/ijbe

DOI number: 10.17358/IJBE.3.2.101

Reichheld F, Schefter P. 2001. E-loyalty: your secret weapon on the web. Harvard Business Review 78(4): 105-115.

Wijanto SH. 2008. Structural Equation Modeling dengan Lisrel 8.8 Konsep dan Tutorial. Jakarta: Graha Ilmu.

Zins A. 2001. Relative attitudes and commitment in customer loyalty models: some experiences in the comercial airline industry. International Journal of Service Industry Management 12(3):269-294. https://doi.org/10.1108/EUM0000000005521. 